\title{
CONSOLIDATED INCINERATION FACILITY (CIF) DEVELOPMENT (U)
}

\author{
by \\ J. T. Carter and J. Morrison by

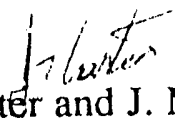 \\ Westinghouse Savannah River Company \\ Savannah River Site \\ Aiken, SC 29808
}

A report for submission to OSTI

and release to general public.

\section{DISCLAIMER}

\begin{abstract}
This report was prepared as an account of work sponsored by an agency of the United States Government. Neither the United States Government nor any agency thereof, nor any of their employees, makes any warranty, express or implied, or assumes any legal liability or responsibility for the accuracy, completeness, or usefulness of any informati pparatus, product, or process disclosed, or represents that its use would not infringe privately owned rights. Refer " ence herein to any specific commercial product, process, or service by trade name, trademark, manufacturer, or otherwise does not necessarily constitute or imply its endorsement, recommendation, or favoring by the United States Government or any agency thereof. The views and opinions of authors expressed herein do not necessarily state or reflect those of the United States Government or any agency thereof.
\end{abstract}

This article was prepared in connection with work done under Contract No. DE-AC0989SR18035 with the U.S. Department of Energy. By acceptance of this article, the publisher and/or recipient acknowledges the U. S. Government's right to retain a nonexclusive, royaltyfree license in and to any copyright covering this article, along with the right to reproduce and to authorize others to reproduce all or part of the copyrighted article.

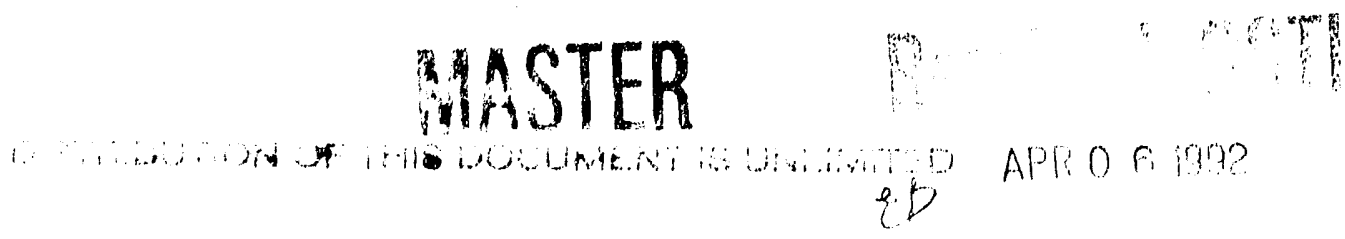




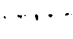
E SAVANNAH RIVER COMPANY
it: I VER LABORATORY

\author{
WSRC-TR-90-327 \\ Keywords: DWPE, CIF, Benzene \\ CC: R. T. Begley, 773-A \\ D. L. MCIntosh, 773-A \\ C. T. Randall, 704-1T \\ L. F. Landon, 704-1T \\ M. J. Plodinec, 773-A \\ M. G. Looper, 676-1T \\ A. L. Blancett, 773-A \\ SRL Records (4)
}

August 1, 1990

$M E M O R A N D U M$

TO: J. R. KNIGHT

FROM: J. T. CARTERfylmot

J. MORRISON 9 Mounde

CIF AITURNATIVE DEVELOPNENTE (u)

\section{INTRODUCTION}

The Defense Waste Processing Eacility (DWPF) will produce an average of 150 gallons per day of a benzene rich organic streaun as a byproduct of precipitate hydrolysis. The organic product is separated and decontaminated by two stages of batch distillation and discharged from the canyon facility. Originally the product was to be stored in a 150,000 gallon storage tank and disposed of by combustion in the Consolidated Incineration Facility (CIF). However, recent delays in design completion and RCRA permitting for the CIF have resulted in an estimated 18 month delay in the facility startup. The startup is currently scheduled for 4293. [1] Since chemical runs in the DWPF are scheduled to begin $12 / 90$ alternative disposal methods for the benzene must be identified.
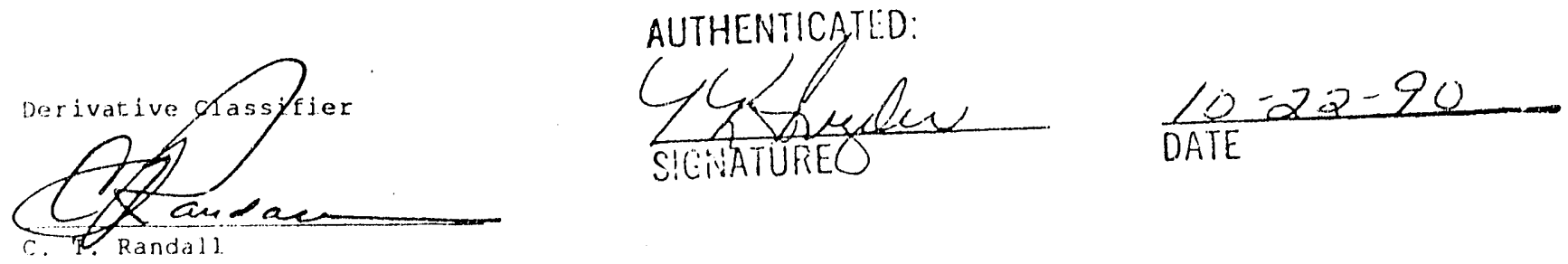
DWPF personnel evaluated four alternative disposal methods[2] and recommended:

- off-site incineration during chemical runs, including the runs which are scheduled to contain mercury, and

- on-site destruction via the commercially available Detoxifier during radioactive runs.

Immediate disposal (vs. storage) of the material produced during the chemical runs is mandated by recent DOE and EPA ruling that 90 day limit for the storage of hazardous waste will be strictly adhered to. Under the original storage and disposal plan the 90 day rule was interpreted to allow storage for longer than 90 days provided the storage facility was permitted and a permanent disposal facility was available (eg. CIF under construction).

On-site destruction of the contaminated material is prudent since there is no EPA (or other government agency) deminimus to allow unrestricted use of the material.

This report details a preliminary review of four technologies suitable to destroy the organic steams. These include:

- A silver catalyzed dissolver,

- A super critical water reactor,

- the Westinghouse Electric Pyrolyzer, and

- the Synthetica Detoxifier.

Each option is discussed below.

The review concurs with the previous recommendation. The commercially available Detoxifier from Synthetica Technologies (Richmond, CA) is the preferred first choice for on-site disposal of the organic stream.

\section{Silver Catalyzed Dissolver}

The silver catalyzed dissolver was developed by the SRL; as a method of dissolving PuO2. This technique is also applicable to the destruction of organic aterials. In the process an electrochemical cell produces silver (II) ions which are circulated to the reaction vessel. The organic materials are attacked by the silver (II) and nitric acid to form carbon dioxide and water. Silver is not consumed in the process and is recycled to the electrochemical cell. The silver is recovered from the reactor bulk solution since the bulk solution must be periodically purged.

To accommodate the DaPF benzene stream, the equipment would operate semi-continuously, with the benzene metered into the reactor at rates below the capacity. The cell is expected to be about $50 \%$ efficient electrically, resulting in the use of about 20 kilowatts/galion of benzene destroyed. [8] The system currently visualized would be made up of modular cells similar to those used in the caustic chlorine industry. 
State of Development

The basic process has been demonstrated on a laboratory scale. A pilot unit capable of destroying 1.5 gallons of benzene per day is expected to be operational in late August.

Lab-scale studies are continuing to define flow sheets and material balance: prior to designing the next pilot unit which will be in the 3-5 gallons/day capacity range.

The process offers proven concepts for the low pressure and low teriperature destruction of benzene. However, a demonstration of 150 galion per day capacity within the current DWPF schedule constraints is not likely. The high power requirement ( 3 megawatts) also detracts from the option.

\section{Supercritical Water Reacter}

Supercritical fluid oxidation is a high temperature, high pressure wet oxidation. Above the critical temperature $\left(374^{\circ} \mathrm{C}\right)$ and pressure (3408 psi), water, organic materials, and gases are completely miscible. Organic cxidation is initiated spontaneously at these conditions and the organics are destroyed rapidly with efficiencies in excess of 99.999 percent. Non-organics are oxidized to acids which can be precipitated out as salts by the addition of bases to the feed. [3]

Such a concept is being developed jointly by Los Alamos National Laboratory and Combustion Engineering. [4] A schematic for the process is contained in Figure 1 . The process consists of the following steps: [3]

1. The waste, as either aqueous solution or a slurry, is pressurized and delivered to the oxidizer inlet. It is heated to super-critical conditions by direct mixing with recycled reactor effluent.

2. Oxy'gen is supplied in the form of compressed air, which is used as the motive fluid in an eductor to provide recycle of a portion of the reactor effluent. This inlet mixture is then a homogeneous phase of air, organics, and supercritical water.

3. The organics are oxidized in a controlled but rapid reaction. The short residence times that are required allow adiabatic operation of the oxidizer. The heat released by combustion of readily oxidized components is sufficient to raise the fluid phase to temperatures at which all organics are oxidized rapidly.

4. The effluent from the oxidizer is fed to a cyclone. The solubility of inorganics in supercritical water is extremely low at the reactor effluent temperatures. Inorganic salts, which are originally present in the feed or which form in the combustion reactions, precipitate out of the fluid phase in the oxidizer and are separated here. 
5. The fluid effluent of the solids separator consists of superheated supercritical water, $\mathrm{N}_{2}$, and $\mathrm{CO}_{2}$. A portion of this is recycled through the eductor to provide supercritical conditions at the oxidizer inlet.

6. The remainder of the effluent is available as a high-temperature, high-pressure fluid for energy recovery. This stream is cooled to a subcritical temperature in a heat exchanger which serves to generate low-pressure or high-pressure steam.

7. Now at a subcritical temperature, the mixture has formed two phases and enters a high-pressure liquid-vapor separator. Almost all of the $\mathrm{N}_{2}$, and most of the $\mathrm{CO}_{2}$ leaves with the gas stream. The liquid consists of water with an appreciable amount of dissolved $\mathrm{CO}_{2}$.

8. The gas and liquid streams are expanded through turbines to extract the avallable energy as power. A portion of the power is used for compression of the inlet air.

9. The effluent from the liquid turbine enters a low-pressure separator. The vapor stream is primarily $\mathrm{CO}_{2}$ which is vented with the gas turbine effluent. The liquid stream is clean water.

State of Development

A bencl. scale unit has been used for over 450 runs, to determine waste destruction efficiencies, develop the process, conduct client waste tests, and conduct basic research. The current reactor has 1650 hours at supercritical conditions. Two pilot scale systems have also been installed at industrial sites. The results of these tests are not available for review. SRL personnel have discussed additional commercial scale unit testing and outlined a 3 year minimum test program.

This technology is not sufficiently developed and demonstrated to meet the DWPF schedule.

\section{Westinghouse Electric Pyrolyzer [5]}

The Electric Pyrolyzer is a thermal device designed to provide complete treatment of wastes. The Pyrolyzer is capable of destroying organic wastes with the immobilization of the inorganic residues in a vitrified, solid product (glass).

The Pyrolyzer utilizes electrical energy to destroy and encapsulate hazardous materials. The pyrolyzer's reaction chamber contains infrared heaters on its upper surface which convey an intense flux of energy to the waste material causing the waste to melt and dissociate. In addition, the lower chamber is fitted with molybdenum electrodes which maintain a molten bath below the infrared heaters. By operating at temperatures in excess of $2400^{\circ} \mathrm{F}$, volatilized organics are dissociated into simpler gas species such 
as carbon monoxide, carbon dioxide, hydrogen and water. Since the system uses electricity as a heat source, and therefore has no need for oxygen or auxiliary fuel. for heat generation, there is minimal generation of off-gas as compared to conventional combustion processes.

A schematic of the Pyrolyzer process is shown in Figure 2. Solid waste materials are fed into the reaction chamber by means of a hopper and ram charger system. Liquids may be pumped directly into the reaction chamber through auxiliary liquid injection ports.

The reaction chamber consists of two sections: the upper dome and the lower tub. The dome contains resistance heaters, each heater drawing approximately 3 kilowatts of electricity. A total of 500 kilowatts is available to power the heaters in the dome. The tub contains six electrodes which pass electric current through the molten material thereby creating heat and electrical resistance. The total power available to the tub electrodes is 300 kilowatts. The internal portion of the reaction chamber is constructed of a refractory material which can resist temperatures up to $3,200^{\circ} \mathrm{C}$. The tub electrodes and the external tub walls are water-cooled during operation. The roof of the dome is cooled by forced air convection.

The reaction chamber off-gases pass through several treatment steps prior to being discharged. Gas treatment includes particulate removal, cooling, and caustic scrubbing to neutralize acid gases produced during processing.

Gas exiting the reaction chamber enters a refractory lined quench chamber which cools the gas with a water spray to approximately $500^{\circ} \mathrm{F}$. After leaving the quench chamber the gas enters a baghouse containing fabric filters which remove the entrained particles. The bags are periodically cleaned with a blast of nitrogen causing the particulate matter to fall to the bottom, where it is removed through a rotary valve an collected in a sealed container.

The gas then passes into an acid gas scrubber where it is neutralized and cooled with a countercurrent flow of caustic solution. The wash solution is adjusted to maintain a salt balance and neutral $\mathrm{pH}$, and is recycled to the scrubber.

The discharge gas composition is monitored continuously for carbon monoxide, carbon dioxide, hydrogen and oxygen. The cleaned, cooled gas is then discharged through a stack to the atmosphere.

\section{State of Development}

The demonstration Pyrolyzer is housed on two standard flat bed trailers, each being 42 feet in length. The system is comprised of a feed system, a reaction chamber, an off-gas treatment system, a cooling water system, and a power/control system. The demonstration unit is currentiy located at the Westinghouse waltz Mill site in Madison, Pennsylvania. 
Testing of the Pyrolyzer has been limited, and little organic hydrocarbon has been processed, although waste oil was included in the test program. The off-gas system is similar to that of the DWPF off-gas system and is designed for particulate removal, not combustion of hydrocarbons. During the DWPF development programs, high organic feeds were processed in the melter and severe off-gas plugaing (sooting) was encountered. Similar problems would be expected in the Pyrolyzer.

The Pyrolyzer would need to be tailored specifically for benzene destruction and would require a major demonstration program to ensure compatibility with the benzene stream.

\section{Detexifier}

Synthetica Technologies, Inc. of Richmond, California has developed equipment to use atmospheric pressure, steam-hydrocarbon

gasification chemistry to destroy a wide variety of hazardous waste. See Figure 4 .

The organic waste is evaporated and heated to $650^{\circ} \mathrm{C}$ in a Moving Bed Evaporator (MBE) using recycle gas as the heat source. The hydrocarbon vapors are first exposed to superheated stearn (contained in the recycle siream) within the evaporator, and steam gasification chemistry starts to occur. At temperatures from 370 to $600^{\circ} \mathrm{C}$ the steam gasification of the hydrocarbon forms $\mathrm{CO}, \mathrm{CO}_{2}, \mathrm{H}_{2} \mathrm{O}, \mathrm{H}_{2}$ and a small amount of $\mathrm{CH}_{4}$. (The hydrogen reacts rapidly and has never been analytically detected in the system.) As the gases pass from the evaporator to the Detoxifier they are heated to higher temperatures (up to $1650^{\circ} \mathrm{C}$ ) in the electrically heated $(40 \mathrm{kw})$ reactor, and the gasification reactions continue to near completion. $[6,7]$ The gases exit the reactor and are cooled before passing through the adsorber. The adsorber contains both selexob for halogen removal, and activated carbon for residual organic, and heavy metal removal. The flow exitjing the adsorber is split, the larger bulk flow is reheated and recycled to vaporize the incoming waste stream, and the smaller flow is passed to a converter. The converter (similar to an automobile catalytic converter) reduces the amount of $\mathrm{CO}, \mathrm{H}_{2}$, and $\mathrm{CH}_{4}$ in the stream by conversion to $\mathrm{CO}_{2}$ and $\mathrm{H}_{2} \mathrm{O}$. This reaction is exothermic and very nearly complete.

\section{State of Development}

The Detoxifier unit has undergone a series of 70 tests conducted under a State of California Hazardous Waste Minimization Waste Program, [7] and has demonstrated destruction efficiencies in excess of 99.99 percent.

The unit is available commercially, although to date there are no units fully permitted and operational. Two prototypes continue to be used for testing wastes and simulated wastes of potential

purchases. 


\section{cenclusions}

The Synthetica Detoxifier is the preferred first choice for on-site disposal of the DWPF benzene. The Detoxifier was selected since it is commercially avaliable, operates below atmospheric pressure, requires only $40 \mathrm{kw}$ of electrical power and has been demonstrated near DWPE capacities with compounds chemically similar to benzene.

The other options reviewed were rejected since they contain one or more of the following features. Low design capacity as compared to the DWPF requirement, high pressure operation, not fully demonstrated with hydrocarbon compounds, or complex cff-gas systems which are not designed for hydrocarbon compounds, and high power consumption.

\section{References}

1. M. J. Looper, personal communication, May 15, 1990.

2. L. M. Papouchado, "contingency Planning in Regard tos the Consolidated Incinerator Facility", OPS-WMPM-90-02, February 1, 1990 .

3. H. Freeman, Innovative Thermal Processes for Treating Hazardous Wastes, Technomic Publishing Company, Inc. Lancaster, Pennsylvania, 1986.

4. C. K. Rofer and G. E. Stret, "Phase II Final report: Oxidation of Hydrocarbons and Oxygenates in Supercritical Water", IA-11700-MS, September 30, 1989.

5. L. R. Eisenstatt, memorandum to D. F. Bickford, NWT-LRE:90:039, March 6, 1990.

6. T. R. Galloway, "The Role of Steam in Lowering PIC's in a Thermal Detoxifier", publication unknown.

7. Synthetica Technologies, Inc, "Thermolytica Detoxifier Performance - Final report for the California Hazardous Waste reduction Grant Program", contract \$86-T0119A-1, August 15, 1989.

8. F. R. Graham to J. T. Carter, personal communication, August 1, 1990.

JTC; dhw 


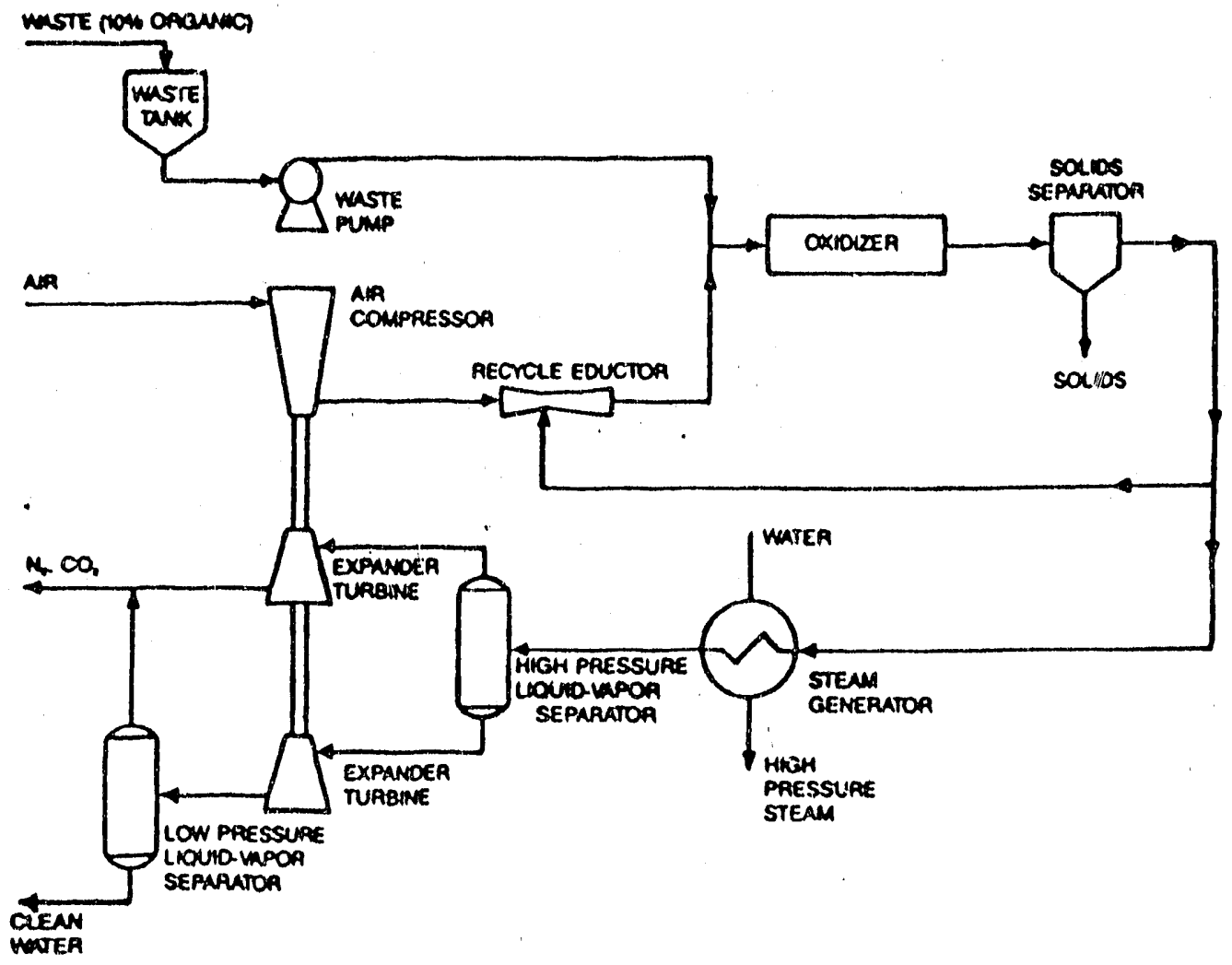

FIGURE 1

SUPERCRITICAL WATER REACTOR 


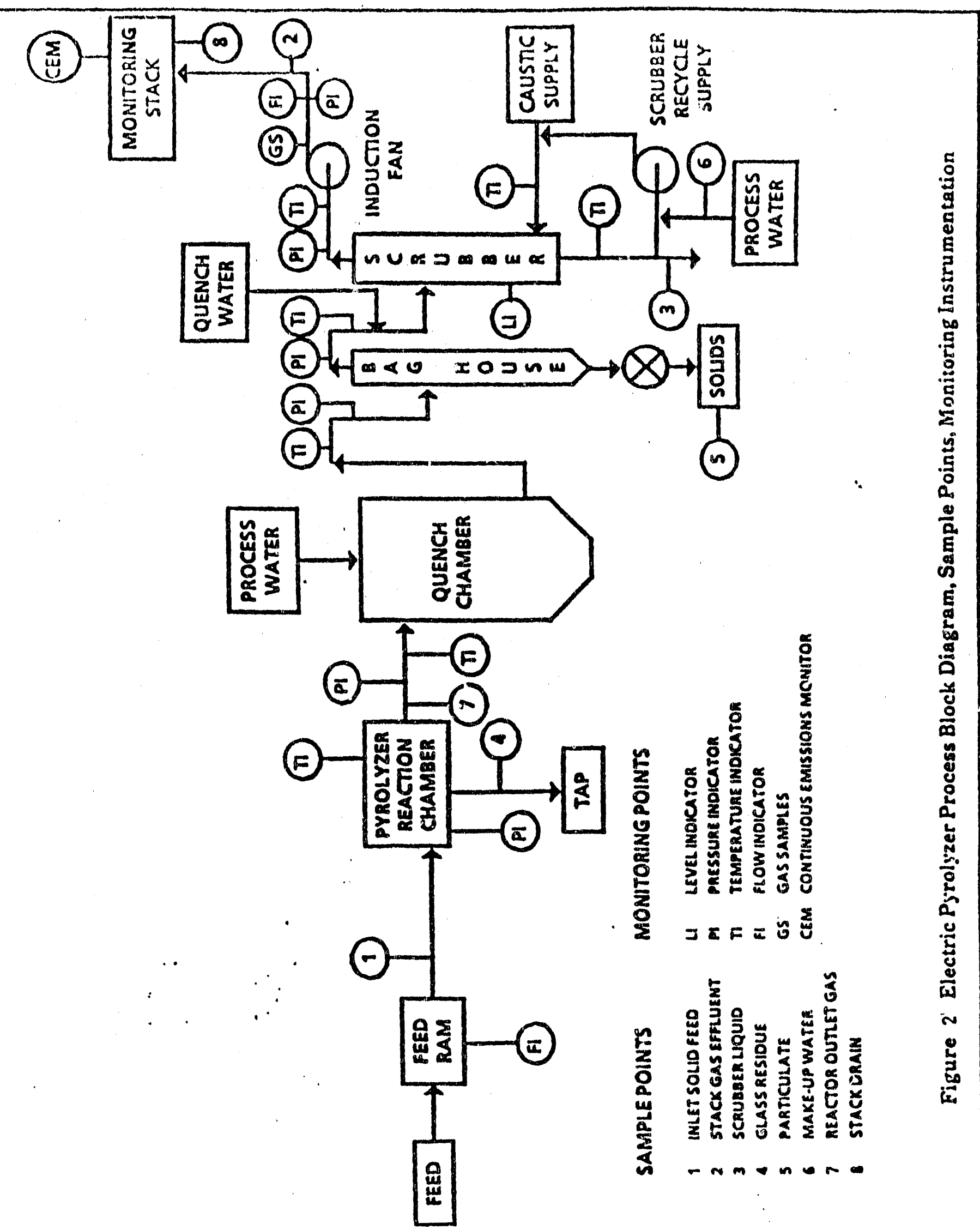




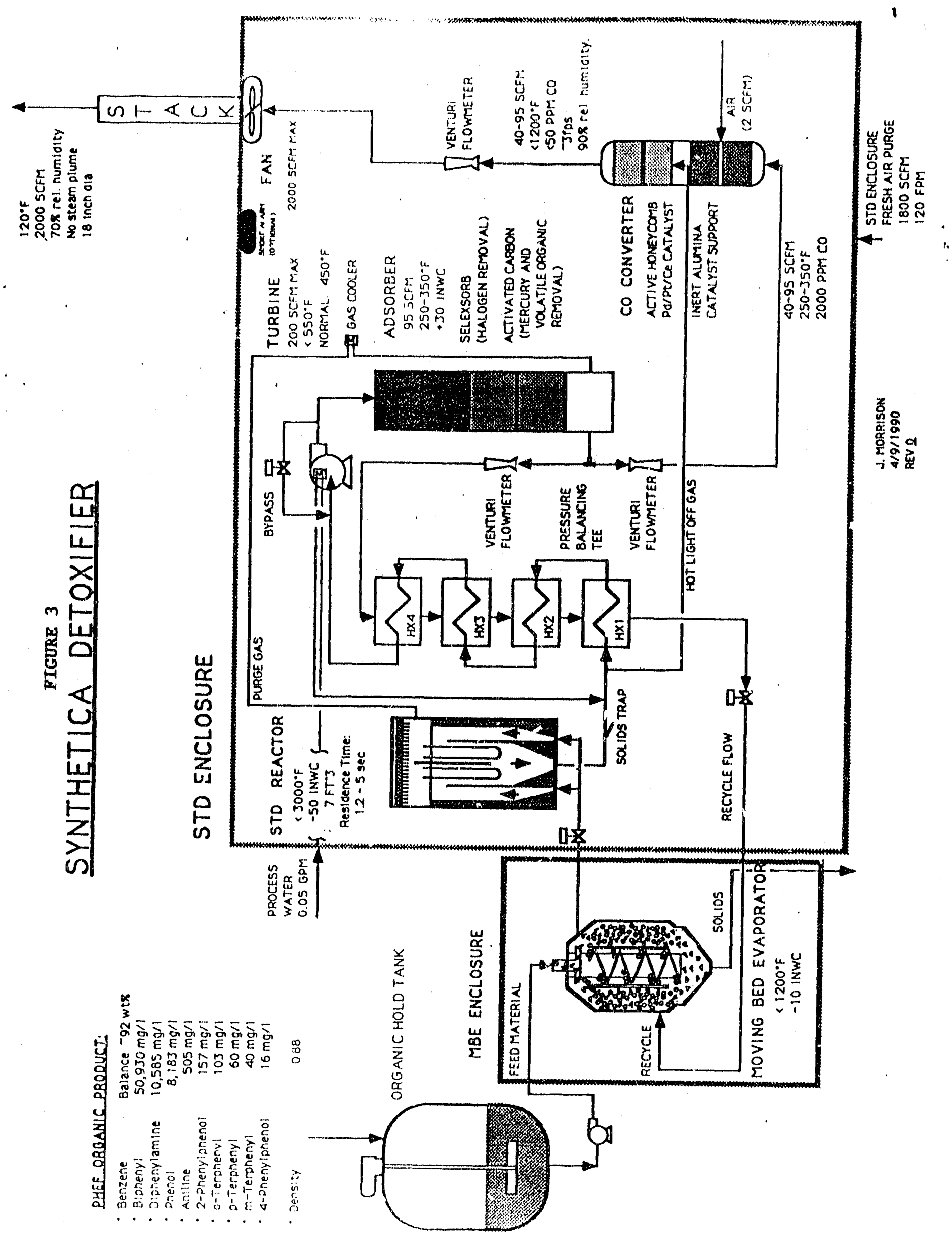



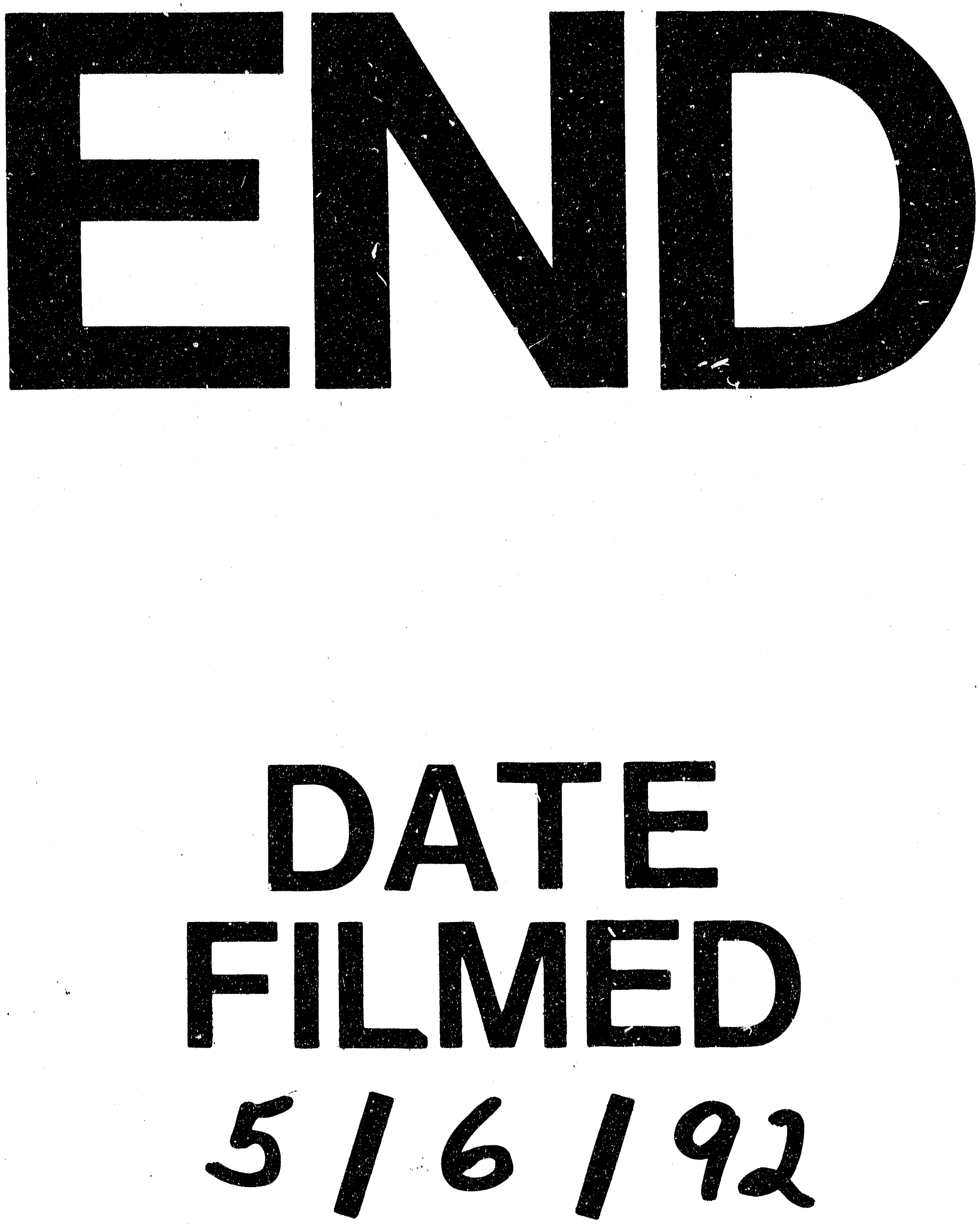

I 